University of Nebraska - Lincoln

DigitalCommons@University of Nebraska - Lincoln

Container and Installation Time Effects on Soil Moisture, Temperature, and Inorganic Nitrogen Retention for an in situ Nitrogen Mineralization Method

\author{
Brian J. Wienhold \\ University of Nebraska-Lincoln, Brian.Wienhold@ars.usda.gov \\ Gary E. Varvel \\ University of Nebraska-Lincoln, gevarvel@windstream.net \\ Wallace W. Wilhelm \\ University of Nebraska-Lincoln, wwilhelm1@unl.edu
}

Follow this and additional works at: https://digitalcommons.unl.edu/usdaarsfacpub

Part of the Agricultural Science Commons

Wienhold, Brian J.; Varvel, Gary E.; and Wilhelm, Wallace W., "Container and Installation Time Effects on Soil Moisture, Temperature, and Inorganic Nitrogen Retention for an in situ Nitrogen Mineralization Method" (2009). Publications from USDA-ARS / UNL Faculty. 608.

https://digitalcommons.unl.edu/usdaarsfacpub/608

This Article is brought to you for free and open access by the U.S. Department of Agriculture: Agricultural Research Service, Lincoln, Nebraska at DigitalCommons@University of Nebraska - Lincoln. It has been accepted for inclusion in Publications from USDA-ARS / UNL Faculty by an authorized administrator of DigitalCommons@University of Nebraska - Lincoln. 


\title{
Container and Installation Time Effects on Soil Moisture, Temperature, and Inorganic Nitrogen Retention for an in situ Nitrogen Mineralization Method
}

\author{
Brian J. Wienhold, Gary E. Varvel, and W. W. Wilhelm \\ Agroecosystem Management Research Unit (AMRU), U.S. Department of \\ Agriculture-Agricultural Research Service, University of Nebraska, Lincoln, \\ Nebraska, USA
}

\begin{abstract}
Mineralization contributes significantly to agronomic nitrogen (N) budgets and is difficult to accurately predict. Models for predicting $\mathrm{N}$ mineralization contributions are needed, and development of these models will require field-based data. In situ mineralization methods are intended to quantify $\mathrm{N}$ mineralization under ambient environmental conditions. This study was conducted to compare soil moisture and temperature in intact soil cores contained in cylinders to those in adjacent bulk soil, compare the effect of two resin-bag techniques on water content of soil within cylinders, and assess the effect of installation duration on inorganic $\mathrm{N}$ retention by resins. The study was conducted at a dryland conventionally tilled corn (Zea mays L.) site and an irrigated notillage corn site in eastern Nebraska. Soil in cylinders was slightly wetter $\left(<0.05 \mathrm{~g} \mathrm{~g}^{-1}\right)$ and warmer $\left(<1{ }^{\circ} \mathrm{C}\right)$ than adjacent soil. Soil water content was $<80 \%$ water-filled pore space (WFPS) at all sampling times and differed little between the two resin-bag techniques. Greater soil water content and temperature conditions (though small) observed during most of the study period likely enhanced $\mathrm{N}$ mineralization within the cylinder compared to $\mathrm{N}$ mineralization in adjacent bulk soil, but the magnitude is likely much less than core-to-core variation normally observed in a field. Installing cylinders for more than 60 days
\end{abstract}

This article is not subject to U.S. copyright law.

Received 26 September 2007, Accepted 21 August 2008

Address correspondence to Brian Wienhold, AMRU, USDA-ARS, 279 Plant Sciences, East Campus, University of Nebraska, Lincoln, NE 68583. E-mail: Brian.Wienhold@ars.usda.gov 
resulted in loss of inorganic $\mathrm{N}$ from resins. Care is needed during installation to ensure that compaction of soil below the cylinder does not impede water movement through the intact soil core. The in situ method utilizing intact soil cores and resin bags replaced at 28- to 40-day intervals is a viable method for measuring $\mathrm{N}$ mineralization.

Keywords: Corn, mineralization, nitrogen, Zea mays L.

\section{INTRODUCTION}

Mineralization contributes significantly to the nitrogen $(\mathrm{N})$ budget in agronomic soils. The amount of $\mathrm{N}$ available due to mineralization is known to be affected by a number of factors including soil type, quantity and quality of crop residue and manure, soil water content, soil temperature, aeration, and management factors such as tillage (Stevenson 1986). Because of the myriad factors affecting mineralization, it remains difficult to accurately predict mineralization rates. A number of laboratory and field procedures have been developed for estimating mineralization (Keeney 1982; Hart et al. 1994). Unfortunately, laboratory methods often correlate poorly with mineralization in the field (Wienhold 2007). Laboratory methods are usually conducted under ideal conditions and may differ greatly from those observed in the field. Field methods may provide more accurate measures of mineralization, but the results are obtained too late for use in current-year fertilizer calculations. Simulation models are needed that accurately predict mineralization under field conditions given different organic inputs (e.g., manure, crop residue) and environmental conditions (temperature and moisture). This is especially true considering the massive impact cellulosic ethanol feedstock production may have on crop-residue use (Perlack et al. 2005; Wilhelm et al. 2004). Efforts are currently under way to develop a model for estimating $\mathrm{N}$ availability in manure-amended soils (Honeycutt et al. 2005). A component of this effort is the use of an in situ intact-core resinbag method for collecting field-based mineralization data.

The in situ intact-core resin-bag method is intended to measure $\mathrm{N}$ mineralization under soil-temperature and water-content conditions existing in the field (Distefano and Gholz 1986). Soil water content and temperature dynamics in the field are known to affect mineralization but are difficult to simulate in laboratory incubations. Adams et al. (1989) concluded that all in situ methods alter the soil environment. Although a number of studies have raised concerns about a modified soil environment within the mineralization vessel, few studies have quantified these differences in agricultural soils. Kolberg et al. (1997) speculated that resins may impair drainage and raise the potential for denitrification in a 
dryland setting, while Brye et al. (2002) concluded that denitrification from soil within cylinders was not significant in a more mesic environment.

Soil water content and temperature have been measured and reported in a number of agronomic in situ mineralization studies but differences between soil in the mineralization vessel and the bulk soil have not been compared (Kolberg et al. 1999; Eghball 2000; Brye et al. 2002). Hanselman, Graetz, and Obreza (2004) compared soil water content and net mineralization among several in situ methods including a core resin technique and a modified core resin technique where soil was mixed with the resin to improve drainage. They found soil water content was greater in core resin cylinders than in the control or modified core resin cylinders. Hanselman, Graetz, and Obreza (2004) used soil in a cylinder without a resin bag as a control rather than the bulk soil, used sieved soil in all cylinders, and installed cylinders in a plant-free plot. Although their results are of value for documenting differences in water content due to the resin bag, their experimental conditions differ from those commonly encountered in most agronomic soils. Our objective was to compare water content and temperature in soil within cylinders to those in adjacent bulk soil for cylinders installed with resin bags or soil + resin bags and then compare net mineralization for cylinders installed the entire season to that for cylinders installed at 28- to 40-day intervals in corn (Zea mays L.) grown on a silty clay loam soil under rainfed or irrigated conditions.

\section{MATERIALS AND METHODS}

The study was conducted at two sites on the Agronomy Farm at the University of Nebraska Agricultural Research and Development Center near Mead, Neb. Both sites were located on well-drained Aksarben (formerly Sharpsburg) silty clay loam (fine smectitic, mesic, Typic Argiudoll) soil. This soil has an average organic-matter content of $31 \mathrm{~g} \mathrm{~kg}^{-1}$ and very high soil-test phosphorus (P) and potassium (K) levels in the surface $7.5 \mathrm{~cm}$. The dryland site was a continuous corn treatment from a dryland cropping system study (Peterson and Varvel 1989). The treatment selected for use in this study has been planted with continuous corn since 1982, receives $180 \mathrm{~kg} \mathrm{Nha}^{-1}$, and has been tilled once or twice with a tandem disk just prior to planting each year. The irrigated site was a continuous corn experiment from a study comparing tillage and residue removal effects on soil carbon and crop yield. The plot selected for use in this study has been in no-tillage continuous corn since 2000 and receives $180 \mathrm{~kg} \mathrm{Nha}^{-1}$ (W. W. Wilhelm, unpublished data). At each site, soil temperature was recorded four times daily using a temperature recorder 
(Onset Computer Corp., Bourne, Mass.*) buried at a depth of $10 \mathrm{~cm}$. Precipitation was recorded at a weather station within $1 \mathrm{~km}$ of both sites. Irrigation amounts at the irrigated site were recorded by technicians that run and maintain the sprinkler system.

The in situ $\mathrm{N}$ mineralization method used was similar to that described by Kolberg et al. (1997). Briefly, a 4.75-cm-i.d. metal cylinder was inserted $17 \mathrm{~cm}$ into the soil and immediately extracted with soil encased within the cylinder. Two $\mathrm{cm}$ of the encased soil were removed from the bottom of the cylinder, and a nylon resin bag was inserted into the bottom of the cylinder. The bottom of the cylinder was then covered with heavy nylon cloth to prevent root entry and the cylinder (with soil, resin bag, and nylon cloth in place) was reinserted into the original hole. Cylinders were inserted randomly between corn plants within rows at each site.

Two resin treatments were compared to assess the effect of the resin bag on water content and temperature within the cylinder. A modified soil-resin mixture (similar to that proposed by Hanselman, Graetz, and Obreza 2004) was prepared by adding equal volumes of soil collected at each study site and a 1:2 mixture of sodium-saturated cation (C-249) and chloride-saturated anion (ASB-1P) resin (Sybron Chemical Inc., Birmingham, N.J.). This resulted in each resin bag containing $20 \mathrm{~g}$ of soil and $10 \mathrm{~g}$ of mixed resin (designated resin + soil). A standard resin mixture (designated as resin) containing a 1:2 mixture of cation-anion resin was prepared, resulting in resin bags containing $10 \mathrm{~g}$ of mixed resin.

At each site, 42 cylinders containing the standard resin treatment and 42 cylinders containing the modified resin treatment were installed on 16 June 2006. On the day of installation, soil samples from the $0-$ to $15-\mathrm{cm}$ depth were collected, water content was determined, and inorganic $\mathrm{N}$ [nitrate $\left(\mathrm{NO}_{3}\right) \quad \mathrm{N}$ and ammonium $\left(\mathrm{NH}_{4}\right) \mathrm{N}$ ] concentration was determined by $2 \mathrm{M}$ potassium chloride $(\mathrm{KCl})$ extraction (Keeney 1982). Inorganic $\mathrm{N}$ was determined in all extracts colorimetrically using a Lachat flow-injection ion analyzer (Zellweger Analytics, Lachat Instruments Div., Milwaukee, Wisc.). For each of the next 12 weeks, three cylinders from each resin treatment were randomly selected from each site for determination of soil temperature and water content. A temperature probe was inserted $10 \mathrm{~cm}$ into the center of each cylinder, and temperature was recorded. The temperature probe was then inserted $10 \mathrm{~cm}$ into bulk soil adjacent to the cylinder, and the temperature was recorded. Selected cylinders were then removed from the soil. In addition, a hand probe was used to collect three soil cores from the 0 - to $15-\mathrm{cm}$

* Any use of trade names is to provide specific information and does not constitute endorsement by the authors or by USDA-ARS. 
depth adjacent to the selected cylinders and composited. All soil samples were returned to the laboratory, and moisture content was determined gravimetrically. On days 27, 62, and 91 after installation, soil and resin from the three cylinders used for water-content determination and from an additional two cylinders were used to determine inorganic $\mathrm{N}$ concentration. Resin from each cylinder was stored at $4{ }^{\circ} \mathrm{C}$ until analysis for inorganic N. Soil was removed from each cylinder, air dried, and ground to pass a $2-\mathrm{mm}$ sieve. Inorganic $\mathrm{N}$ in soil was determined as described previously. Inorganic $\mathrm{N}$ in resin was extracted by five 15-min serial extractions with $2 \mathrm{M} \mathrm{KCl}$ (Kolberg, Westfall, and Peterson 1997). Inorganic $\mathrm{N}$ was determined in all extracts as described previously.

To assess the effect of installation time on inorganic $\mathrm{N}$ recovery, five additional cylinders of each resin type were installed at each site 27 and 62 days after the initial cylinder installation. Cylinders installed on day 27 were collected on day 62, and cylinders installed on day 62 were collected on day 91. Soil water content and inorganic $\mathrm{N}$ concentration in soil and resin were determined as described previously. Inorganic $\mathrm{N}$ was summed over the three installation intervals (cylinders installed from day 0 to day $27+$ cylinders installed from day 27 to day $62+$ cylinders installed from day 62 to day 91). Inorganic-N content as a function of time for the cylinders installed on day 0 and collected on days 27, 62, and 91 (designated as season-long installation) was compared to the summed total for cylinders installed and collected every 27 to 30 days (designated as 4 -week installation). Inorganic $\mathrm{N}$ present on day 0 was subtracted from that measured in cylinders and resin, and therefore the subsequently measured inorganic $\mathrm{N}$ was assumed to represent net mineralized $\mathrm{N}$.

In this study, the experimental units are the individual cylinders, which were installed randomly within the planted rows of corn at the two sites. Data from the two sites were analyzed independently. Analysis of variance (SAS Inst. 1985) was used to determine differences in soil temperature and water content using location (soil in the cylinder compared to bulk soil adjacent to the cylinder), resin treatment (resin vs. resin + soil), and time as main effects. Differences in net mineralized $\mathrm{N}$ were compared using resin treatment, installation treatment (season-long vs. 4-week installation), and time as main effects. Differences were declared significant at the 0.05 probability level, but probability levels for discussed treatment effects will be specified in the text. Differences among means were determined by pairwise comparisons made with the DIFF option of the LSMEANS statement. The Tukey adjustment option of the LSMEANS statement was used to protect the experimental error rate. 


\section{RESULTS}

\section{Environmental Conditions}

At the dryland site, average daily soil temperature ranged from 17.7 to $27.4{ }^{\circ} \mathrm{C}$ and averaged $23.5^{\circ} \mathrm{C}$ over the study period (Figure 1A). Both sites received a total of $29.8 \mathrm{~cm}$ of precipitation while the cylinders were in the soil. Precipitation was not distributed evenly throughout the season with only one substantial precipitation event during the first 50 days of the study (Figure 1A). Average daily soil temperature at the irrigated site ranged from 18.1 to $25.2{ }^{\circ} \mathrm{C}$ and averaged $22.5{ }^{\circ} \mathrm{C}$ (Figure 1B). In addition to the $29.8 \mathrm{~cm}$ of precipitation, this site received an additional $15.2 \mathrm{~cm}$ of irrigation while the cylinders were in the soil. Irrigation resulted in a more even distribution of water inputs at this site when compared to the dryland site.

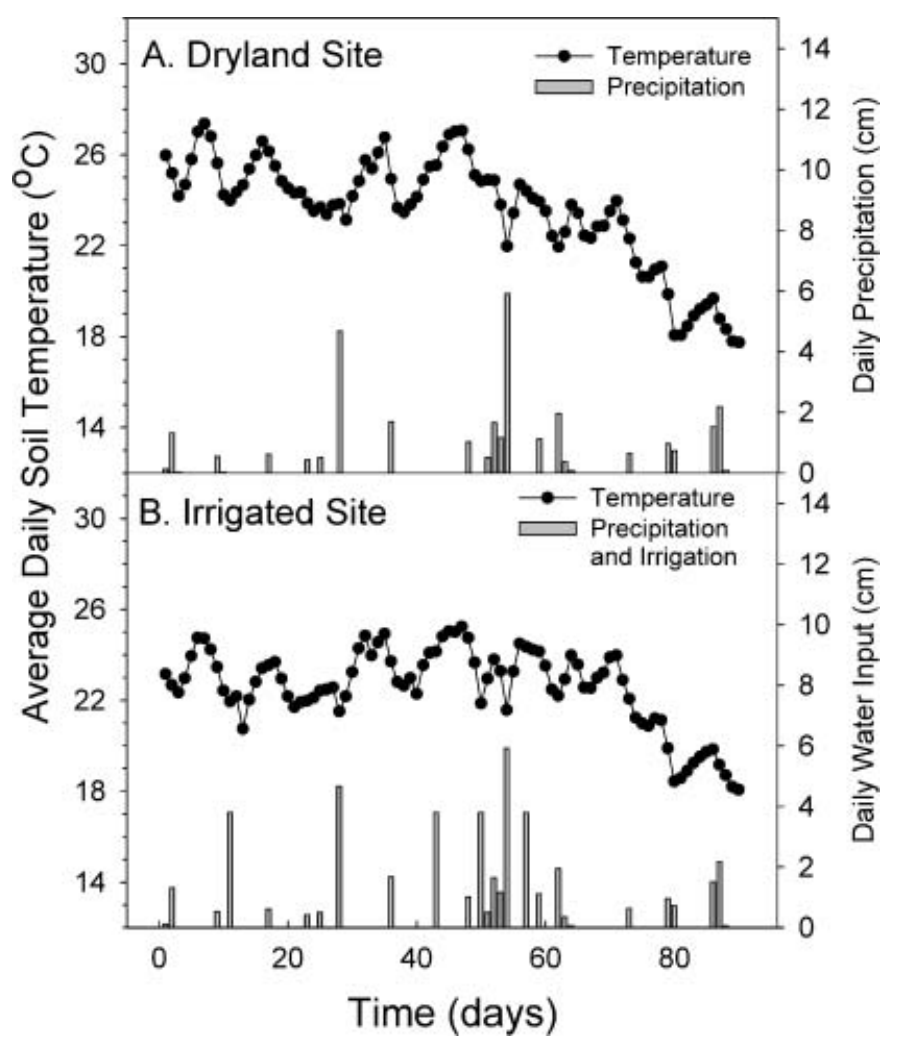

Figure 1. Average daily temperature and water inputs for the (A) dryland and (B) irrigated study sites. 


\section{Cylinder Effects on Soil Temperature}

Soil temperature in cylinders at the dryland site was greater than bulk soil temperature, but this difference never exceeded $1{ }^{\circ} \mathrm{C}$ (Figure $2 \mathrm{~A}$ ). During the first 30 days that the cylinders were installed, there was a greater difference in soil temperature between soil in the cylinder and bulk soil for the resin + soil treatment than for the resin treatment $(\mathrm{p}<0.0001)$. After the first substantial precipitation event, the difference in soil temperature between soil in the cylinder and bulk soil was similar for the two resin treatments (Figure $2 \mathrm{~A}$ ).

At the irrigated site, soil temperatures varied with time $(\mathrm{p}<0.0001)$ and differed between soil in the cylinder and bulk soil $(\mathrm{p}<0.0006)$. Soil temperatures in the cylinder were greater than in the bulk soil for all but two sample times. With the exception of the first sampling period, when soil inside cylinders in the resin + soil treatment were $0.9{ }^{\circ} \mathrm{C}$ warmer than the adjacent bulk soil, soil temperature differences between the bulk soil and soil in the cylinder were $<0.5^{\circ} \mathrm{C}$ (Figure 2B).

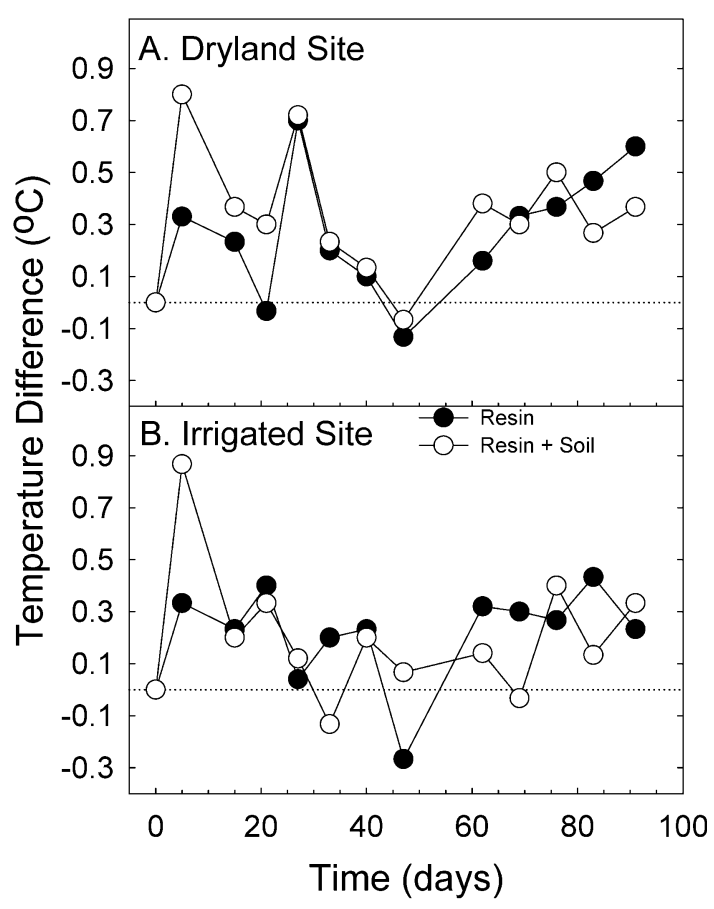

Figure 2. Temperature difference between soil in mineralization cylinders and adjacent bulk soil as a function of resin bag treatment at the (A) dryland and (B) irrigated study sites. 


\section{Cylinder Effects on Soil Water Content}

Bulk soil water content at the dryland site varied during the season $(\mathrm{p}<0.0001)$ with dry conditions early in the season and moister conditions late in the season (Figure 3A). Bulk soil water content was less than that corresponding to $60 \%$ water-filled pore space (WFPS) from day 0 to 50. A water content corresponding to $60 \%$ WFPS is optimum for soil respiration and nitrification (Linn and Doran 1984). After day 60, bulk soil water content was equal to or greater than that corresponding to $60 \%$ WFPS but did not reach a water content corresponding to $80 \%$ WFPS. A water content corresponding to $80 \%$ WFPS represents soil water conditions where denitrification activity increases rapidly (Linn and Doran 1984). Bulk soil water content at the irrigated site was greater than that for the dryland site early in the season (Figure 3B). Compared to the dryland site, water content at the irrigated site varied little during the

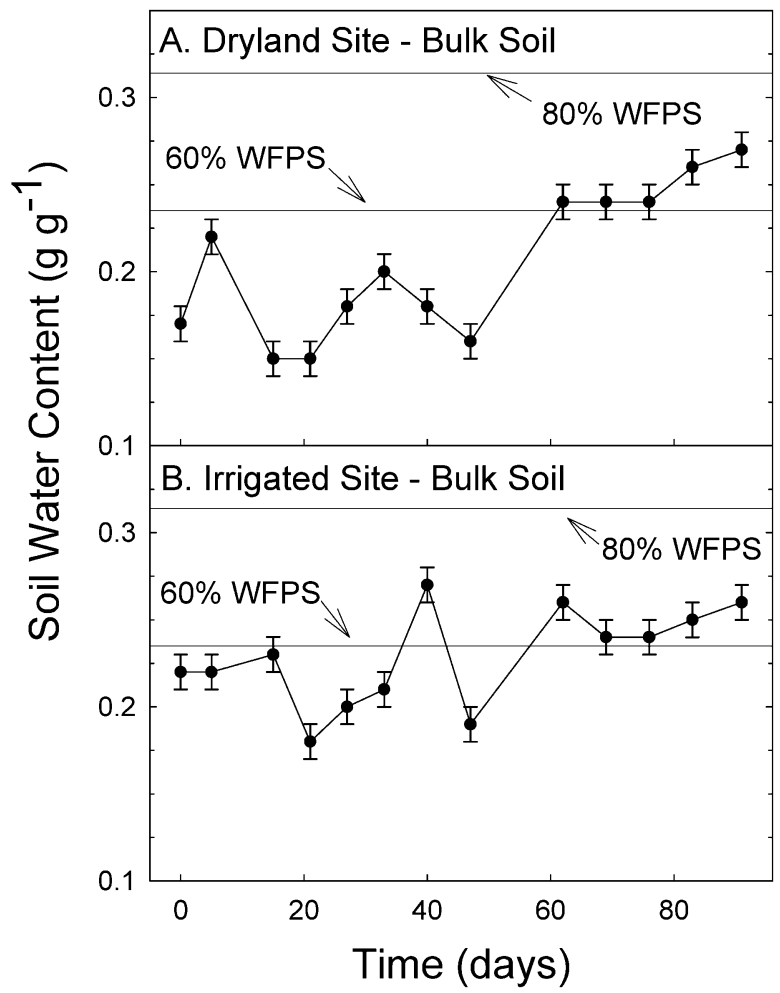

Figure 3. Bulk soil water content as a function of sampling time at the (A) dryland and (B) irrigated study sites. Error bars represent \pm one standard error of the mean. 
study, and bulk soil water content was near that corresponding to $60 \%$ WFPS for the entire study period.

At the dryland site, water content in the cylinders was greater than that in the bulk soil early in the season and was similar late in the season (Figure 4A), resulting in a time by location (bulk vs. cylinder soil) interaction $(\mathrm{p}<0.0001)$. Greater water content in the cylinders early in the season likely resulted from roots extracting water from the bulk soil and being excluded from the soil in the cylinders. After day 60 , there was a resin treatment effect that differed between installation times (resin treatment by installation time interaction $p=0.026$ ), with water content being similar in both resin treatments for cylinders that were in place all season long but greater water content in cylinders that were installed on day 62. Cylinders were installed on day 62 into very moist soil, and there was likely compaction of soil below the cylinder that impeded drainage. We assume cylinders installed all season long did not have this compaction issue and drainage was maintained because they were installed when the soil was much drier (Figure 3). The water content in

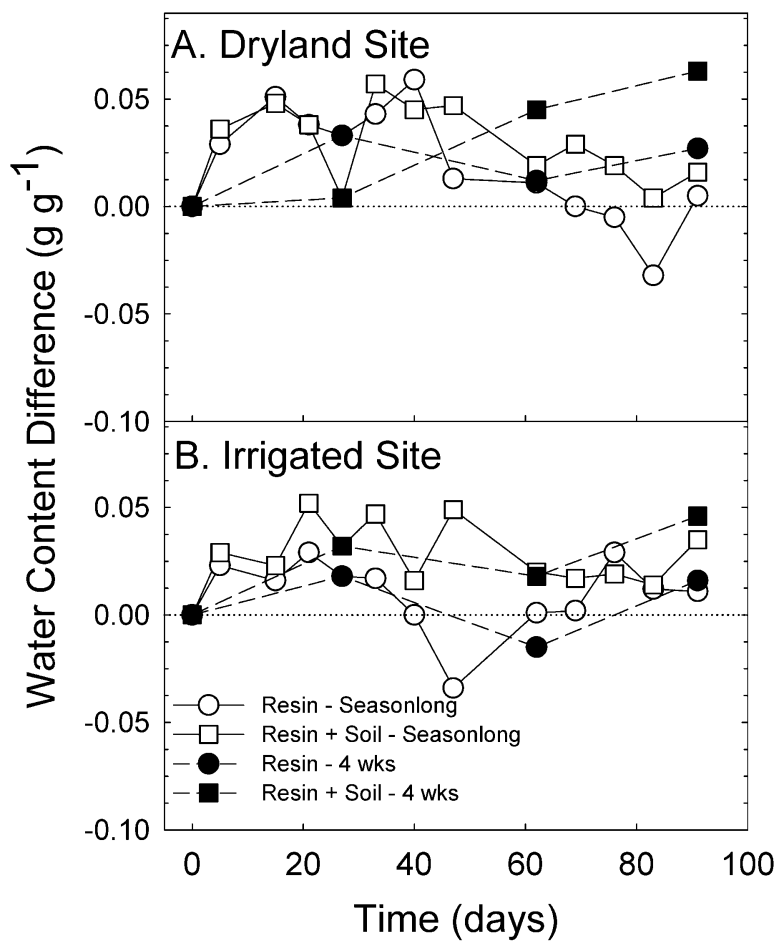

Figure 4. Water-content differences between soil in mineralization cylinders and adjacent bulk soil as a function of resin-bag treatment and installation time at the (A) dryland and (B) irrigated study sites. 
the resin + soil treatment installed on day 62 approached $80 \%$ WFPS, and there was the potential for denitrification losses in these cylinders.

At the irrigated site, water content for soil in cylinders was similar to that for the bulk soil at sampling times at the start and end of the season (Figure 4B). On days 20, 27, 33, and 47, soil in cylinders of the resin + soil treatments (square symbols in figure) had a greater water content than bulk soil, whereas soil in cylinders of the resin treatments (circle symbols in figure) had a similar or lesser water content than bulk soil, resulting in a time by resin treatment by soil interaction $(\mathrm{p}=0.007)$. Differences in water content between soil in cylinders and bulk soil were relatively small, and it appears unlikely that water content exceeded $80 \%$ WFPS where denitrification activity would potentially increase (Linn and Doran 1984). For sampling times when the difference in water content between the cylinder and bulk soil differed between resin treatments, soil in cylinders in the resin + soil treatment usually had a greater water content. The resin + soil treatment was proposed to minimize drainage problems associated with the discontinuity in particle size between the resin and soil (Hanselman, Graetz, and Obreza 2004). Our results from a silty clay loam do not support the need for this modification in the use of resin for retaining inorganic $\mathrm{N}$ from soil leachate.

\section{Net Mineralized N}

At the dryland site, net mineralized $\mathrm{N}$ increased with time in all treatments $(\mathrm{p}<0.0001)$. There were no differences in mineralized $\mathrm{N}$ among resin treatments or installation times at any sampling date (Figure 5A). Mineralization of $\mathrm{N}$ began slowly, likely due to immobilization by crop residue incorporated during the pre-plant tillage operation, increased during the second sampling interval, and decreased in rate during the third sampling interval. There was relatively good agreement among estimates of mineralized $\mathrm{N}$ for both resin treatments and both installation times for cylinders collected on days 27 and 62. In contrast, the estimates of mineralized $\mathrm{N}$ for day 91 were highly variable. These results agree with those of Hanselman et al. (2004) in that long-term installation of resin bags appears to result in poor retention of inorganic $\mathrm{N}$. Measured mineralized $\mathrm{N}$ at the dryland site was $123 \mathrm{kgha}^{-1}$ for cylinders inserted every 4 weeks. This value agrees well with the $127 \mathrm{~kg} \mathrm{ha}^{-1}$ of nonfertilizer $\mathrm{N}$ incorporated into grain and stover in a fertilizer recovery study conducted in this same treatment (Varvel and Peterson 1990).

At the irrigated site, net mineralized $\mathrm{N}$ increased linearly over the first two sampling times for all installation time and resin treatments (Figure 5B). Mineralized N continued to increase linearly in the cylinders 


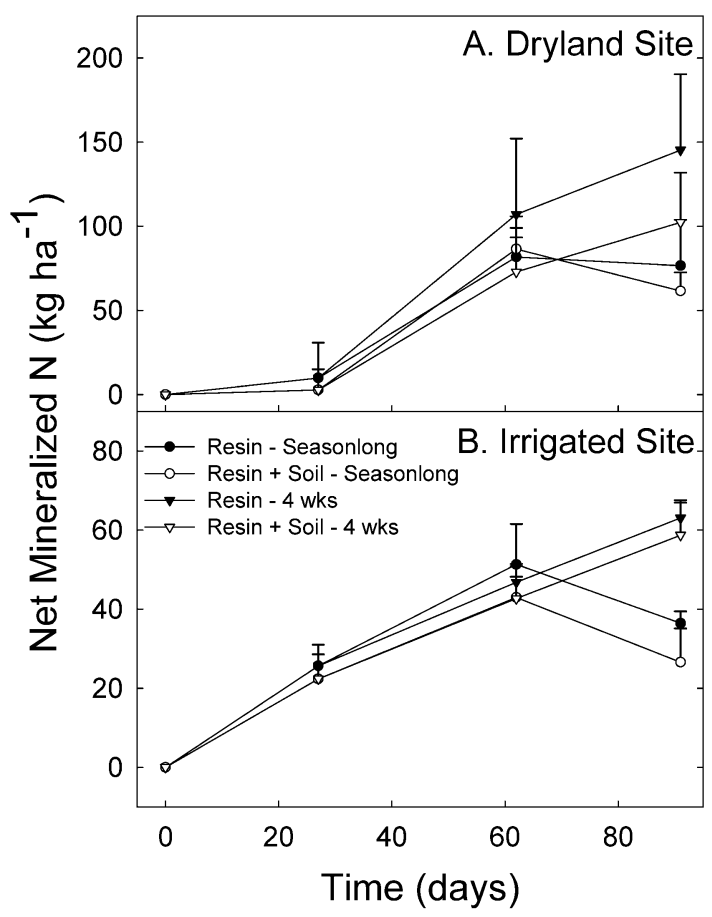

Figure 5. Net mineralized $\mathrm{N}$ as a function of resin-bag treatment and installation time at the (A) dryland and (B) irrigated study sites. Error bars represent one standard error of the mean.

that were installed on day 62, whereas inorganic $\mathrm{N}$ content in cylinders installed on day 0 declined for both resin treatments, resulting in a installation treatment by time interaction $(\mathrm{p}=0.003)$. The decrease in inorganic $\mathrm{N}$ in cylinders installed for the entire season supports findings regarding poor retention of inorganic $\mathrm{N}$ when resin is left in the soil for $>$ 45 to 60 days (Hanselman, Graetz, and Obreza 2004). Measured mineralized $\mathrm{N}$ at the irrigated site was about half that at the dryland site. Less mineralization at this site is likely related to the no-tillage method and therefore no incorporation of crop residue, whereas at the dryland site incorporation results in faster decomposition of the previous year's crop residue.

\section{DISCUSSION}

Soil within cylinders had a greater water content and was warmer than adjacent bulk soil. Previous studies have raised concerns about watercontent differences between sampled soil and bulk soil (Kolberg et al. 
1997; Hanselman, Graetz, and Obreza 2004). Greater water content is a concern because this may create more favorable conditions for mineralization within the cylinder than in bulk soil, or, if water content approaches $80 \%$ WFPS, denitrification may become significant, resulting in $\mathrm{N}$ loss and underestimation of mineralization. Within the range of temperatures and water contents observed in this study, the magnitude of the differences in temperature and water content, and the effects temperature and water content have on mineralization (Cassman and Munns 1980), we expect the effect of the modified soil environment on $\mathrm{N}$ mineralization to be smaller $(<10 \%)$ than the within-treatment variation observed in in situ mineralization studies (e.g., $\mathrm{cv}=49 \%$ for this study; $\mathrm{cv}=10$ to $43 \%$ reported by Eghball 2000).

Greater soil water content within cylinders can result from lack of plant uptake because of root exclusion or modified drainage resulting from the textural difference at the base of the cylinder between the soil and resin. We attribute the slightly greater water contents $\left(<0.05 \mathrm{~g} \mathrm{~g}^{-1}\right)$ measured in our study primarily to root exclusion. However, in the silty clay loam soil at our study sites, we measured water contents approaching $80 \%$ WFPS on one occasion. This observation was for cylinders installed on day 62 into very moist soil. We speculate that installation under these conditions resulted in compaction of soil at the base of the cylinder and that this compaction reduced drainage through the cylinder. Mixing soil with the resin as proposed by Hanselman, Graetz, and Obreza (2004) to reduce the textural difference between soil and resin did not appear to improve drainage from the cylinders in our study.

Poor retention of inorganic $\mathrm{N}$ on resin beyond 60 days was observed at both sites. Others have also observed poor retention over extended installation times (Hanselman, Graetz, and Obreza 2004). There are at least two mechanisms by which retention could be reduced: denitrification of adsorbed nitrate and displacement of adsorbed nitrate by subsequent leachate. Recovery of nitrate in leaching studies has been reported at 80 to $90 \%$ of that applied (Schnabel, Messier, and Purnell 1993; Wyland and Jackson 1993). Schnabel (1983) concluded that nitrate retained by resin was stable, as greater than $90 \%$ was recovered after up to 12 weeks. Schnabel, Messier, and Purnell (1993) also determined that greater than $95 \%$ of the nitrate leached through the resin was retained until $50 \%$ of the exchange sites were occupied and then retention decreased. For the resin type and amount used in the current study, Eghball (2000) calculated that the resins would retain inorganic $\mathrm{N}$ equivalent to $275 \mathrm{~kg} \mathrm{Nha}^{-1}$. The cause for less and more variable recovery of inorganic $\mathrm{N}$ after 60 days is unclear, but our results suggest that installing cylinders for short time periods ( $\sim 28$ to 40 days) and summing the results over the period of interest will provide estimates of 
mineralization under environmental conditions more similar to those existing in the field than can be imposed in a laboratory method.

Adams et al. (1989) concluded that all in situ mineralization methods result in an altered soil environment. We have documented the magnitude of that modification for an intact-soil-core resin-bag method. Care during collection of intact cores (especially regarding soil moisture status) and installation of resin bags is needed to maintain drainage from soil within the cylinder. Care during installation should minimize differences in soil moisture within cylinders and adjacent bulk soil. Limiting the duration of installation to 28 to 40 days will ensure retention of inorganic $\mathrm{N}$ by resins. Documenting differences in soil moisture and temperature should be included in future in situ studies as this information may help explain observed results. The in situ method we assessed can be used to compare management effects on mineralization rates, provide field-based data for model development and validation, and quantify mineralization contributions to crop $\mathrm{N}$ budgets for developing improved fertilizer recommendations.

\section{REFERENCES}

Adams, M. A., P. J. Polglase, P. M. Attiwill, and C. J. Weston. 1989. In situ studies of nitrogen mineralization and uptake in forest soils: Some comments on methodology. Soil Biology and Biochemistry 21:423-429.

Brye, K. R., J. M. Norman, E. V. Nordheim, S. Thompson Gower, and L. G. Bundy. 2002. Refinements in an in-situ core technique for measuring net nitrogen mineralization in moist, fertilized agricultural soil. Agronomy Journal 94:864-869.

Cassman, K. G., and D. N. Munns. 1980. Nitrogen mineralization as affected by soil moisture, temperature, and depth. Soil Science Society of America Journal 44:1233-1237.

Distefano, J. F., and H. L. Gholz. 1986. A proposed use of ion-exchange resins to measure nitrogen mineralization and nitrification in intact soil cores. Communications in Soil Science and Plant Analysis 17:989-998.

Eghball, B. 2000. Nitrogen mineralization from field-applied beef cattle feedlot manure or compost. Soil Science Society of America Journal 64:2024-2030.

Hanselman, T. A., D. A. Graetz, and T. A. Obreza. 2004. A comparison of in situ methods for measuring net nitrogen mineralization rates of organic soil amendments. Journal of Environmental Quality 33:1098-1105.

Hart, S. C., J. M. Stark, E. A. Davidson, and M. K. Firestone. 1994. Nitrogen mineralization, immobilization, and nitrification. In Methods of Soil Analysis, Part 2: Microbiological and Biochemical Properties (Soil Science Society of America Book Series No.5), ed. R. W. Weaver et al., 985-1018. Madison, Wisc.: SSSA.

Honeycutt, C. W., T. S. Griffin, B. J. Wienhold, B. Eghball, S. L. Albrecht, J. M. Powell, B. L. Woodbury, K. R. Sistani, R. K. Hubbard, and H. A. Torbert. 2005. Protocols for nationally coordinated laboratory and field research on 
manure nitrogen mineralization. Communications in Soil Science and Plant Analysis 36:2807-2822.

Keeney, D. R. 1982. Nitrogen-availability indices. In Methods of Soil Analysis, Part 2: Chemical and Microbial Properties, 2nd ed., ed. A. L. Page, R. H. Miller, and D. R. Keeney, 711-733. Madison, Wisc.: American Society of Agronomy.

Kolberg, R. L., B. Rouppet, D. G. Westfall, and G. A. Peterson. 1997. Evaluation of an in situ net soil nitrogen mineralization method in dryland agroecosystems. Soil Science Society of America Journal 61:504-508.

Kolberg, R. L., D. G. Westfall, and G. A. Peterson. 1999. Influence of cropping intensity and nitrogen fertilizer rates on in situ nitrogen mineralization. Soil Science Society of America Journal 63:129-134.

Linn, D. M., and J. W. Doran. 1984. Effect of water-filled pore space on carbon dioxide and nitrous oxide production in tilled and nontilled soils. Soil Science Society of America Journal 48:1267-1272.

Perlack, R. D., L. L. Wright, A. F. Turhollow, R. L. Graham, B. J. Stokes, and D. C. Erbach. 2005. Biomass as feedstock for a bioenergy and bioproducts industry: The technical feasibility of a billion-ton annual supply (DOE/GO102005-2135 and ORNL/TM-2005/66). Oak Ridge, Tenn.: Oak Ridge National Laboratory. Available at http://feedstockreview.ornl.gov/pdf/billion_ton_ vision.pdf

Peterson, T. A., and G. E. Varvel. 1989. Crop yield as affected by crop rotation and N rate, III: Corn. Agronomy Journal 81:735-738.

SAS Institute. 1985. SAS user's guide. Cary, N.C.: SAS Institute Inc.

Schnabel, R. R. 1983. Measuring nitrogen leaching with ion exchange resin: A laboratory assessment. Soil Science Society of America Journal 47:1041-1042.

Schnabel, R. R., S. R. Messier, and R. F. Purnell. 1993. An evaluation of anion exchange resin used to measure nitrate movement through soil. Communications in Soil Science and Plant Analysis 24:863-879.

Stevenson, F. J. 1986. Cycles of Soil: Carbon, Nitrogen, Phosphorus, Sulfur, Micronutrients. New York: Wiley.

Varvel, G. E., and T. A. Peterson. 1990. Nitrogen fertilizer recovery by corn in monoculture and rotation systems. Agronomy Journal 82:935-938.

Wienhold, B. J. 2007. Comparison of laboratory methods and an in situ method for estimating nitrogen mineralization in an irrigated silt-loam soil. Communications in Soil Science and Plant Analysis 38:1721-1732.

Wilhelm, W. W., J. M. F. Johnson, J. L. Hatfield, W. B. Voorhees, and D. R. Linden. 2004. Crop and soil productivity response to corn residue removal: A literature review. Agronomy Journal 96:1-17.

Wyland, L. J., and L. E. Jackson. 1993. Evaluating nitrate recovery by ionexchange resin bags. Soil Science Society of America Journal 57:1208-1211. 